open $\odot$ access

\title{
When Shall Coronavirus Disease-19 Stop? Review of Literature
}

\author{
Ahmed M. El-Malky ${ }^{1,2 \star}$, Waad H. Al-Kathiri ${ }^{3,4}$, Azza A. El Nouman ${ }^{5}$ \\ ${ }^{1}$ Morbidity and Mortality Unit Supervisor, King Saud Medical City, Riyadh, Saudi Arabia; ${ }^{2}$ Department of Public Health and \\ Community Medicine, Theodor Bilharz Research Institute, Academy of Scientific Research, Ministry of Scientific Resarch, Cairo, \\ Egypt; ${ }^{3}$ Department of Clinical Pharmacy Services, King Saud University Medical City, Riyadh, Saudi Arabia; ${ }^{4}$ Department of \\ Clinical Pharmacy, College of Pharmacy, King Saud University, Riyadh, Saudi Arabia; ${ }^{5}$ Professor of Public Health, Faculty of \\ Medicine, Cairo University, Egypt
}

Edited by: Mirko Spiroski Citation: El-Malky AM, Al-Kathiri WH, El Nouman AA When Shall Coronavirus Disease-19 Stop? Review of Literature. Open Access Maced J Med Sci. 2020 May 10;
8(T1):75-81. https://doi.org/10.3889/oamims.2020.4844 Keywords: Covid19; Pandemic; Medication; Economic; Psychology; Political *Correspondence: Ahmed M. El-Malky, Morbidity and Mortality Unit Supervisor, King Saud Medical City, Riyadh, Saudi Arabia. E-mail: aelmalky@ksu.edu.sa Received: 10-Apr-2020 Revised: 15-Apr-2020 Copyright: ๑ 2020 Ahmed M. El-Malky, Waad H. Al-Kathiri, Azza A. El Nouman. Al-Kathiri, Azza A. EI Nouman.
Funding: Publication of this article was financially Funding: Publication of this article was financially
ppported by the Scientific Foundation SPIROSKI, Skopje, Republic of Macedonia Competing Interests: The authors have declared that no
competing interests exist Competing Interests: The authors have declared that no
competing interests exist under the terms of the Creative Commons Attribution-

\begin{abstract}
In December 2019, a new coronavirus, now labeled as severe acute respiratory syndrome coronavirus 2, induced an episode of acute atypical respiratory illness started in Wuhan, Province of Hubei, China. The illness triggered by this virus was called coronavirus disease-19 (COVID-19). The infection is spread within humans and has triggered a global pandemic. The amount of death tolls continues to increase and a growing number of countries have been driven to create social barriers and lock-ups. The shortage of tailored counseling remains an issue. Epidemiological researches have shown that elderly patients are more vulnerable to serious diseases, while children tend to have milder symptoms. Here, we checked the latest understanding of this disease and found a possible explanation of the potential sequel and the expectations for the future.
\end{abstract}

\section{Introduction}

On the morning of 1 day, the world will not wake up to a message, phone, or urgent news that the crisis is over and the ponds of the pandemic have all receded in one go [1]. It is essential that no one knows when the ordeal of humanity will end with the emerging coronavirus "coronavirus disease-19 (COVID 19)" with certainty [2]. In spite of the optimistic visions that herald the diminishing fears and decreasing the growing losses currently, other visions and analyses are expecting the worse for a year coming or over [3].

The problem that closes all doors of anticipation is that the current crisis is not a war that could end with a truce or a peace agreement, and not a recession or economic distress that is sufficient for countries to allocate an urgent support and revitalization package [4]. The world is locked in a struggle with an eccentric microscopic organism, for which complete information is not yet available, so it is difficult to surround the stakes of the crisis or to predict the behaviors of the virus, and all we have until now: A map of actions and measures, a list of expectations and possibilities, and an open horizon on hopes, aspirations, and fears that are not completely negative, and it is not guaranteed to reach its positive points in time [5], [6].

\section{Rapid Pandemic and Mysterious Organism}

Even now, the picture is not entirely clear, even among specialists from doctors and microbiologists. The most alarming thing about the crisis is that the new coronavirus "COVID 19" has disturbing characteristics in terms of proliferation, infection, and periods of survival outside living cells, and the most disturbing is that the virus is mysterious for us, so what we know about it is much less than what we do not know [6], [7]. Fears are compounded by preliminary weightings from researchers and doctors that involve the possibility that this huge unknown area is dynamic, that is, it is a changing state in terms of characteristics and activity, and not a constant that can build the equation on it and reach a sound solution to it due to the ability to 
control the variables associated with the pathology or the conditions of transmission and yet infection [7].

On January 2020, the World Health Organization said it had no evidence of transmission of "COVID 19" between humans, indicating that it may differ from the well-known Corona family, including the severe acute respiratory syndrome (SARS) and Middle East respiratory syndrome viruses, or that it is closer to the "Hantavirus" family, which is transmitted from rodents to humans, but not between humans and each other [7], [8]. The important thing is that the aforementioned health statement pushed many countries to a state of reassurance and caused the delay in adopting serious measures to confront, to the extent that many parties now accuse the organization of being the reason behind the spread of the epidemic [8].

\section{Political Versus Medical Point of View}

The US President announced in his daily briefing that his country decided to suspend its regular support to the World Health Organization (Washington is the largest contributor to the budget of the International Organization), because it provides false information about the emerging epidemic of coronavirus, according to his statement [9]. Beyond the possibilities of political recruitment, whether in his speech, or accusing the organization of bias toward China, or even accusing China itself of blinding and concealing facts, the only thing that is reached is that the current epidemic represents a real danger, first because it is evil and rapidly spreading and second because we are unable to understand and surround it until now, and most importantly, we were not prepared for this type of longterm crisis, and that point alone will cause confusion in plans and prolong the ordeal [10].

\section{Current Precautions versus Curfews and Panic}

Actually, we are facing an "INFODEMIC" rather than a pandemic. Previous reports stated that the virulence and infectivity of measles, smallpox, and SARS were more than COVID-19, 15 times, 10 times, and 3 times, respectively. Case fatality in Ebola virus is 6 times higher than COVID 19. Reports stated that many points of weakness in the virus-like inability of the virus to be transmitted and survive in high temperatures, which means a high possibility of cessation in the summer season. Global panic and massive vibrations in social media will only make the problem worse [11].

Prisoning of people at homes and $24 \mathrm{~h}$ curfews will not participate in problem solving. On contrary, it may lead to other problems such as depression, anxiety, obesity, suicidal attempts, moreover, the economic and financial crisis at the individual and community level. Like it or not, a day will come, when the international systems will collapse, and the governments will be forced to leave people to confront the virus with simple precautions and personal immunity [12].

Simple precautions and well-cultured people are enough to stop the virus. Handwashing, masks, gloves, and practicing of proper social distancing can safely replace curfews and panic. Governments can prevent the crowd by closing malls and social clubs, not by prisoning people at homes. Prevent the places of crowdedness but not prison people [13].

\section{When does the Epidemic Stop?}

Despite touching the level of a million and a half infections, in 4 months, and recording about 85,000 deaths, which exceeds $5.6 \%$, with a spread in more than 212 countries and regions around the world, it cannot be said that we have reached the peak level so far [13]. The World Health Organization says that most countries in the world do not provide true and accurate figures on infections, and Italian press reports indicated that the analysis of the blood of healthy donors in one of the affected towns of the Lombardy region had proven the presence of antibodies to the virus in $70 \%$ of them. Whether this information is correct or not, it is certain that the actual infections are more than what the health services calculate around the world [14].

The previous truth may seem reassuring to some when approaching the scene and trying to foresee its future horizons, as the underlying meaning is that the epidemic is not necessarily dangerous and deadly for everyone and that thousands or millions of people crossed it without feeling or feeling their country [15]. However, unlike that optimistic case, the matter is not reassuring, first because we do not know the virus fully, and then we have no evidence that it may not return or that those who recovered from it are immune from its recurrence again and second because we do not know these potential cured patients. So by default, all of us remain in existing danger even for those who were not aware that they were infected and recovered [16].

The most dangerous thing is that even if the real numbers are a 1000 times the numbers currently registered, this does not represent only $20 \%$ of the world's population, and the extent of the epidemic is still open to 6 billion people who could be infected in the future near. In practice, the cessation of the epidemic is not related to any precautionary measures. Rather, it could be a reason for the complexity of the crisis in the future [17]. The global economy does not bear the broad and long-term closure, and health institutions 
cannot work with that operational power and the pace indefinitely, and at some point, everyone may have to reduce the oppressive grip of the epidemic circumstance, which may cause an explosion or an acute wave of infections with a more massive bill because it comes after the economy and state structures have been completely exhausted [18].

The calculations are all complicated, and in a simple way, it can be said that the epidemic stop station is linked to biological inputs that cannot be induced or predicted, and the stage of its decline or its transformation into a transient seasonal disease will not be achieved before acquiring a wide-ranging societal immunity (at least $60 \%$ of people) [19]. It means that nearly 5 billion should be infected and recovered from the virus or acquires the virus without infection [20].

\section{The Pessimistic Hypothesis}

The optimistic forecasts hope that the crisis will pass within weeks, whether due to high temperatures and droughts during the summer or with metaphysical hopes that the infection will decline, even if the scientific opinion so far has been the opposite [21]. Pessimistic expectations not only indicate the continuation of the epidemic beyond the middle of next year only but augur well for its renewal in fierce epidemiological waves for several years before it subsides and takes a simple seasonal form, just like the current flu [22]. Between the two possibilities, scientists stand without the ability to resolve the matter yet [23].

Almost and approximately every hundred years, the universe has been attacked fiercely by a wave of an influenza pandemic [24], [25]. The last one was the Spanish flu pandemic in 1918, which was responsible for the mortality of 50 million of people over $<10$ years [26], [27]. Until it has been transformed to what's known nowadays by seasonal influenza, which used to come to everyone every year without significant side effects [28], [29]. This could be due to the adaptation of the human immunity for this virus across human being generations [30], [31]. According to this hypothesis and according to the pessimistic view, the outcome of the previous pandemic will be achieved by the current pandemic, with one difference [32], [33]. The number of mortalities will not reach 50 million in 10 years, but in 30-50 years because of the exaggerated precautions and curfews [34], [35]. This could be like some sort of natural selection [36], [37]. Family of influenza viruses characterized by periodic genetic mutation in the form antigenic shifts, every 10 years, and antigenic drifts every year [38], [39].

What we are going through today is one of the severest antigenic shifts of the influenza virus [40], [41]. Almost a new inscrutable virus not used to be transmitted from human to human [42], [43]. It was only a zoonotic cycle and man is not involved except by viral mutation [44], [45]. Our target is to elicit a natural active immunity in the whole population through allowing of subclinical/clinical infections and herd immunity [46], [47]. From the beginning of the pandemic, the countries which applied strict $24 \mathrm{~h}$ curfew have shown no decrease in case numbers on the epidemic curve [48], [49]. After curfew practicing, the cases continued to increase [50], [51]. The number of cases detected as well as fatalities in underdeveloped countries which did not apply any precautions was less than developed countries who applied strict precautions [52], [53]. This may be due to lack of modern diagnostic technology or may be due to the high population immunity or may be due to herd immunity acquired by the spread of subclinical infection all over the nation, no one knows [54], [55].

\section{The Epidemic between, Medicine and Vaccine}

To this moment, the SARS Cove 2 mutations or the emerging COVID 19 have not yet been severed [56], [57]. The main host of the virus is the bat that has a huge reservoir of that viral family, but the human infection did not come from a bat [58], [59]. China said that the virus was transmitted to humans from an anteater with a squid ant, but available studies indicated a similarity observation of about $94 \%$ with the possible validity of that [60], [61]. The information, however, cannot be confirmed, and until the moment also, information is conflicting about the "zero" case, which was the first human infection, and many Chinese media outlets published reports on more than three people as the first infection [62], [63].

In contrast, studies varied regarding the periods of virus activity outside the host cells and on different surfaces, and some said that it is transmitted in the air, and doctors differed in the clinical symptoms of patients, and the response to health care varied even with the installation of variables of geography, weather, age, and patient history [64], [65]. In short, we do not yet know "COVID 19" as it should, and by default, our predictions about it cannot be completely accurate unless we have more cases, more basic research, and no fear to face [66], [67]. We must give up the dread and have the courage to know more about the virus, not just follow the precautions for fear of infection [68], [69].

Access to an effective drug in the face of clinical symptoms, mitigating the effects of the virus and then curing it can be an important step toward reducing the severity of the epidemic and escaping from its economic, political, and psychological repercussions, and reaching a "vaccine" can lead to a 
state of reassurance, stability, and ability to restore an aspect of natural daily life, at least in the vital sectors and productive institutions [70]. Contrary to positive expectations committed to logic, or hopes driven by the state of fear and the search for reassurance, even if they are false, the medicine and vaccine will not be the end of the epidemic as some people think, not because they will miss the effectiveness in facing it and restraining it, but because the equations of testing, production, and sufficiency have its pressures, and most importantly, the crisis is not a war that stops its fire completely with armistice or surrender of the virus under the bombing of laboratories and drug factories [71].

\section{Gradual Exit and Extended Effects}

At present, world leaders and experts sit inside laboratories and hospitals [72]. Everyone thinks that the crisis will not end far away from epidemiology, microbiology, and pharmacology, but most likely they will move away from a little, not beyond the horizons of scientific solutions, but rather close to the panoramic view and integrated solutions that balance the considerations of science and economics with the lives and lives of people [73]. Decision-makers must leave their offices and go down to the ground to reconsider the planning of streets and squares [74]. Doctors, scientists, and researchers will work on their important path, but others will turn to idle paths, but they are equally important [75].

Many societies will gradually return to life, with strict precautions and a constant level of fear [76]. Perhaps Germany's pathway to conducting immunological examinations and tests and allowing those who are found to be less at risk to return to work and re-pump blood into the arteries of the economy may be adopted [77]. That vision may expand or be circulated temporarily, especially since even with the arrival of a guaranteed drug or an effective vaccine, the crisis will not end immediately, fears will remain, and the potential for risk will be open until the epidemiological freeze is confirmed, to begin the chain of gradual decline associated with the priority of countries and sectors and who are getting on innovative drugs and return to a normal life first [78].

The economic and social effects of the epidemic, the state of panic and psychological fractures that have afflicted millions of people around the world, confirm that the virus sizing or drug suppression station will not be the end of the crisis [79]. It will take months to restore the psyche of those affected and longer months to repair the economic cracks and perhaps years to restore confidence in the existing global system and people return to a full normal life [80]. The first periods will witness confusion in visions, evil demand for goods and services, a sharp rise in prices with diminishing savings and benefits, and the ability of banking institutions to activate the investment machine [81]. Those potential prospects mean that the pace of exiting the repercussions of the crisis may be slower than overcoming the epidemic itself and that we may live as "COVID 19" fears and its effects for years to come, even if we close the epidemic page a year later as pessimists expect, or within weeks as optimists preach [82].

\section{Conclusion}

Our vision for the current situation could be summarized in the following points; the most affected categories are diabetic patients and those who were immunocompromized. Most of cases are subclinical infection and the disease transmitted among people by herd immunity. No need for exaggerated or arbitrary measures, just infection control precautions, immunity augmentation, and treatment of diabetes. we recommend the conduction of studies to prove that medical staff who were positive for COVID 19, didn't know about their disease except at the time of study.

\section{References}

1. Coronaviridae Positive Sense RNA Viruses Positive Sense RNA Viruses; 2011. Available from: https://www.talk.ictvonline.org/ ictv-reports/ictv_9th_report/positive-sense-rna-viruses-2011/w/ posrna_viruses/222/coronaviridae. [Last accessed on 2020 Mar 05].

2. Cui J, Li F, Shi ZL. Origin and evolution of pathogenic coronaviruses. Nat Rev Microbiol. 2019;17(3):181-92. PMid:30531947

3. Zhou P, Fan H, Lan T, Yang XL, Shi WF, Zhang W, et al. Fata swine acute diarrhoea syndrome caused by an HKU2-related coronavirus of bat origin. Nature. 2018;556(7700):255-8. PMid:29618817

4. Zhou P, Yang XL, Wang XG, Hu B, Zhang L, Zhang W, et al. A pneumonia outbreak associated with a new coronavirus of probable bat origin. Nature. 2020;579(7798):270-3. PMid:32015507

5. Gorbalenya AE, Baker SC, Baric RS, de Groot RJ, Drosten C, Gulyaeva AA, et al. Severe acute respiratory syndromerelated coronavirus: The species and its viruses a statement of the Coronavirus Study Group. Nat Microbiol 2020;58(9):81-9. https://doi.org/10.1101/2020.02.07.937862

6. Zhu N, Zhang D, Wang W, Li X, Yang B, Song J, et al. A novel coronavirus from patients with pneumonia in China, 2019. N Engl J Med. 2020;382(8):727-33. PMid:31978945

7. Lu H, Stratton CW, Tang Y. Outbreak of pneumonia of unknown etiology in Wuhan, China: The mystery and the miracle. J Med Virol. 2020;92(4):401-2. https://doi.org/10.1002/jmv.25678 PMid:32085850 
8. Chen N, Zhou M, Dong X, Qu J, Gong F, Han Y, et al. Epidemiological and clinical characteristics of 99 cases of 2019 novel coronavirus pneumonia in Wuhan, China: A descriptive study. Lancet. 2020;395(10223):507$13 . \quad$ https://doi.org/10.1016/s0140-6736(20)30211-7 PMid:32007143

9. Huang C, Wang Y, Li X, Ren L, Zhao J, Hu Y, et al. Clinical features of patients infected with 2019 novel coronavirus in Wuhan, China. Lancet. 2020;395:497-506.

10. Tan W, Zhao X, Ma X, Wang W, Niu P, Xu W, et al. A novel coronavirus genome identified in a cluster of pneumonia cases Wuhan, China 2019-2020. China CDC Wkly. 2020;2:61-2.

11. Johns Hopkins University Coronavirus COVID-19 (2019-nCoV). Available from: https://www.gisanddata. maps.arcgis.com/apps/opsdashboard/index.html\#/ bda7594740fd40299423467b48e9ecf6. [Last accessed on 2020 Feb 25].

12. China CDC Weekly. Available from: http://www.weekly.chinacdc. $\mathrm{cn} /$ news/TrackingtheEpidemic.htm. [Last accessed on 2020 Feb 25].

13. Worldometer: Coronavirus Update (Live). Available from: https:// www.worldometers.info/coronavirus. [Last accessed on 2020 Feb 25].

14. Klassen, D. Updated COVID-19 Statistics. Available from: https://www.nucleuswealth.com/articles/updated-coronavirusstatistics-cases-deaths-mortality-rate. [Last accessed on 2020 Mar 03].

15. World Health Organization. Director-General's Opening Remarks at the Media Briefing on COVID-19-11 March 2020. Available from: https://www.who.int/dg/speeches/detail/whodirector-general-s-opening-remarks-at-the-media-briefing-oncovid-19---11-march-2020. [Last accessed on 2020 Mar 16].

16. Fan $Y$, Zhao $K$, Shi ZL, Zhou $P$. Bat Coronaviruses in China. Viruses. 2019;11(3):210. PMid:30832341

17. Cyranoski D. Did pangolins spread the China coronavirus to people? Nature. 2020;67(7):783-90. https://doi.org/10.1038/ d41586-020-00364-2

18. Ksiazek TG, Erdman D, Goldsmith CS, Zaki SR, Peret T, Emery S, et al. A novel coronavirus associated with severe acute respiratory syndrome. N Engl J Med. 2003;348(20):1953-66. PMid:12690092

19. Andersen K, Rambaut A, Lipkin WI, Holmes EC, Garry RF. The Proximal Origin of SARS-CoV-2. Available from: http:// www.virological.org/t/the-proximal-origin-of-sars-cov-2/398. [Last accessed on 2020 Feb 25]. https://doi.org/10.1038/ s41591-020-0820-9

20. Kuba K, Imai Y, Rao S, Gao H, Guo F, Guan B, et al. A crucial role of angiotensin converting enzyme 2 (ACE2) in SARS coronavirus-induced lung injury. Nat Med. 2005;11(8):875-9. https://doi.org/10.1038/nm1267 PMid: 16007097

21. Glowacka I, Bertram S, Muller MA, Allen P, Soilleux E, Pfefferle S, et al. Evidence that TMPRSS2 activates the severe acute respiratory syndrome coronavirus spike protein for membrane fusion and reduces viral control by the humoral immune response. J Virol. 2011;85(9):4122-34. https://doi.org/10.1128/jvi.02232-10 PMid:21325420

22. Heurich A, Hofmann-Winkler H, Gierer S, Liepold T, Jahn O, Pohlmann S. TMPRSS2 and ADAM17 cleave ACE2 differentially and only proteolysis by TMPRSS2 augments entry driven by the severe acute respiratory syndrome coronavirus spike protein. $\mathrm{J}$ Virol. 2014;88(2):1293-307. https://doi.org/10.1128/jvi.02202-13 PMid:24227843

23. Shulla A, Heald-Sargent T, Subramanya G, Zhao J, Perlman S, Gallagher T. A transmembrane serine protease is linked to the severe acute respiratory syndrome coronavirus receptor and activates virus entry. J Virol. 2011;85(2):873-82. $\quad$ https://doi.org/10.1128/jvi.02062-10 PMid:21068237

24. Zhou P, Yang XL, Wang XG, Hu B, Zhang L, Zhang W, et al. Discovery of a novel coronavirus associated with the recent pneumonia outbreak in humans and its potential bat origin. Microbiology. 2020;56(8):359-70.

25. Schnirring L. More Outbreak Details Emerge as COVID-19 Cases top 70,000. Available from: http://www.cidrap.umn.edu/ news-perspective/2020/02/more-outbreak-details-emergecovid-19-cases-top-70000. [Last accessed on 2020 Feb 25].

26. The Epidemiological Characteristics of an Outbreak of 2019 Novel Coronavirus Diseases (COVID-19) China; 2020. Available from: http://www.weekly.chinacdc.cn/en/article/id/e53946e2c6c4-41e9-9a9b-fea8db1a8f51. [Last accessed on 2020 Feb 25].

27. PM Abe Asks All of Japan Schools to Close Over Coronavirus Reuters; 2020. Available from: https://www.reuters.com/article/ us-china-health-japan-idUSKCN20LOBI. [Last accessed on 2020 Feb 27].

28. CNN World; Yeung J, Marsh J, Kottasová I, Vera A. March 15 Coronavirus News. Available from: https://www.cnn.com/world/ live-news/coronavirus-outbreak-2-03-15-20-intl-hnk/index.html. [Last accessed on 2020 Mar 16].

29. CDC Coronavirus Disease 2019 (COVID-19) Resources for K-12 Schools and Childcare Programs. Available from: https:// www.cdc.gov/coronavirus/2019-ncov/community/schoolschildcare/index.html. [Last accessed on 2020 Mar 16].

30. Delamater PL, Street EJ, Leslie TF, Yang YT, Jacobsen KH. Complexity of the basic reproduction number (R0). Emerg Infect Dis J. 2019;25(1):1-4. https://doi.org/10.3201/eid2501.171901 PMid:30560777

31. Zhao S, Lin Q, Ran J, Musa SS, Yang G, Wang W, et al. Preliminary estimation of the basic reproduction number of novel coronavirus (2019-nCoV) in China, from 2019 to 2020: A datadriven analysis in the early phase of the outbreak. Int $\mathrm{J}$ Infect Dis. 2020;92:214-7. https://doi.org/10.1101/2020.01.23.916395 PMid:32007643

32. World Health Organization. Novel Coronavirus China. Available from: http://www.who.int/csr/don/12-january-2020-novelcoronavirus-china/en. [Last accessed on 2020 Feb 25].

33. CDC Coronavirus Disease 2019 (COVID-19). Available from: https://www.cdc.gov/coronavirus/2019-ncov/about/ transmission.html. [Last accessed on 2020 Mar 03].

34. Guerra FM, Bolotin S, Lim G, Heffernan J, Deeks SL, Li Y, et al. The basic reproduction number (R0) of measles: A systematic review. Lancet Infect Dis. 2017;17(12):e4208. $\quad$ https://doi.org/10.1016/s1473-3099(17)30307-9 PMid:28757186

35. Marangi L, Mirinaviciute G, Flem E, Tomba GS, Guzzetta G, BlasioBF, etal.Thenatural history ofvaricellazostervirusinfectionin Norway: Further insights on exogenous boosting and progressive immunity to herpes zoster. PLoS One. 2017;12(5):e0176845. https://doi.org/10.1371/journal.pone.0176845 PMid:28545047

36. Kampf G, Todt D, Pfaender S, Steinmann E. Persistence of coronaviruses on inanimate surfaces and their inactivation with biocidal agents. J Hosp Infect. 2020;104(3):24651. https://doi.org/10.1016/j.jhin.2020.01.022 PMid:32035997

37. vanDoremalenN,BushmakerT,KareshWB,MunsterVJ.Stabilityof Middle Eastrespiratory syndrome coronavirus in milk. Emerg Infect Dis. 2014;20(7):1263-4. https://doi.org/10.3201/eid2007.140500 PMid:24960335

38. Warnes SL, Little ZR, Keevil CW. Human coronavirus 229E remains infectious on common touch surface materials. mBio. 2015;6(6):e01697-15. https://doi.org/10.1128/mbio.01697-15 PMid:26556276 
39. Yeung J. China is Literally Laundering its Money to Contain the Coronavirus-CNN. Available from: https://www.edition.cnn. com/2020/02/17/asia/china-is-disinfecting-cash-coronavirusintl-hnk-scli/index.html. [Last accessed on 2020 Feb 25].

40. ZouL, RuanF,HuangM, Liang L, HuangH,HongZ, etal.SARS-CoV-2 viral load in upper respiratory specimens of infected patients. NEngl $\mathrm{J}$ Med. 2020;382(12):1177-9. https://doi.org/10.1056/nejmc2001737 PMid:32074444

41. Li Q, Guan X, Wu P, Wang X, Zhou L, Tong $Y$, et al. Early transmission dynamics in Wuhan, China, of novel coronavirus infected pneumonia. N Engl J Med. 2020;382(13):1199-207. PMid:31995857

42. Guan W, Ni Z, Hu Y, Liang W, Ou C, He J, et al. Clinical characteristics of 2019 novel coronavirus infection in China. Respir Med. 2020;45(33):245-55.

43. BackerJA,KlinkenbergD, WallingaJ. Incubationperiod of2019nove coronavirus (2019-nCoV) infections among travellers from Wuhan, China, 20-28 January 2020. Euro Surveill. 2020;25(5):2000062. https://doi.org/10.2807/1560-7917.es.2020.25.5.2000062 PMid:32046819

44. Coronavirus: Wuhan Speeds Up Testing and Treatment of Patients, East Asia News and Top Stories the Straits Times. Available from: https://www.straitstimes.com/asia/east-asia/ coronavirus-wuhan-speeds-up-testing-and-treatment-ofpatients. [Last accessed on 20202 Mar 15].

45. Bai Y, Yao L, Wei T, Tian F, Jin DY, Chen L, et al. Presumed asymptomatic carrier transmission of COVID-19. JAMA. 2020;323(14):1406-7. https://doi.org/10.1001/jama.2020.2565 PMid:32083643

46. Rothe C, Schunk M, Sothmann P, Bretzel G, Froeschl G, Wallrauch C, et al. Transmission of 2019-nCoV infection from an asymptomatic contact in Germany. N Engl J Med. 2020;382(10):970-1. https://doi.org/10.1056/nejmc2001468 PMid:32003551

47. Lipsitch M, Swerdlow DL, Finelli L. Defining the epidemiology of covid-19 studies needed. N Engl J Med. 2020;382(13):1194-6. https://doi.org/10.1056/nejmp2002125 PMid:32074416

48. Zhao Y, Zhao Z, Wang Y, Zhou Y, Ma Y, Zuo W. Single-cell RNA expression profiling of ACE2, the putative receptor of Wuhan 2019-nCov. Bioinformatics. 2020;24(10):901-11. https://doi. org/10.1101/2020.01.26.919985

49. Cai G. Tobacco-use disparity in gene expression of ACE2, the receptor of 2019-nCov. Life Sci. 2020;87(12):872-89. https://doi. org/10.20944/preprints202002.0051.v1

50. Liu S, Zhang M, Yang L, Li Y, Wang L, Huang Z, et al. Prevalence and patterns of tobacco smoking among Chinese adult men and women: Findings of the 2010 national smoking survey. J Epidemiol Community Health. 2017;71(2):154-61. https://doi.org/10.1136/jech-2016-207805 PMid:27660401

51. Wei M, Yuan J, Liu Y, Fu T, Yu X. Zhang ZJ. Novel Coronavirus InfectioninHospitalized Infants Under1YearofAgeinChina.JAMA. 2020;323(13):1313-4. https://doi.org/10.1001/jama.2020.2131 PMid:32058570

52. Wax RS, Christian MD. Practical recommendations for critical care and anesthesiology teams caring for novel coronavirus (2019-nCoV) patients. Can J Anesth. 2020;67(5):568-76. https://doi.org/10.1007/s12630-020-01591-x

53. Chu CM. Role of lopinavir/ritonavir in the treatment of SARS: Initial virological and clinical findings. Thorax. 2004;59(3):252-6. https://doi.org/10.1136/thorax.2003.012658 PMid: 14985565

54. Sheahan TP, Sims AC, Graham RL, Menachery VD, Gralinski LE, Case JB, et al. Broad-spectrum antiviral GS-5734 inhibits both epidemic and zoonotic coronaviruses. Sci Transl Med. 2017;9(396):eaal3653. https://doi.org/10.1126/scitranslmed.aal3653 PMid:28659436

55. Mulangu S, Dodd LE, Davey RT, Mbaya OT, Proschan M, Mukadi $\mathrm{D}$, et al. A randomized, controlled trial of ebola virus disease therapeutics. N Engl J Med. 2019;381(24):2293303. PMid:31774950

56. Wang $\mathrm{M}$, Cao R, Zhang L, Yang $\mathrm{X}$, Liu J, Xu M, et al. Remdesivir and chloroquine effectively inhibit the recently emerged novel coronavirus (2019-nCoV) in vitro. Cell Res. 2020;30(3):269-71. https://doi.org/10.1038/s41422-020-0282-0 PMid:32020029

57. Holshue ML, DeBolt C, Lindquist S, Lofy KH, Wiesman J, Bruce $\mathrm{H}$, et al. First case of 2019 novel coronavirus in the United States. N Engl J Med. 2020;382(10):929-36. PMid:32004427

58. NIH (National Institute of Allergy and Infectious Diseases). NIH Clinical Trial of Remdesivir to Treat COVID-19 Begins. Available from: https://www.niaid.nih.gov/news-events/nih-clinical-trialremdesivir-treat-covid-19-begins. [Last accessed on 2020 Feb 27].

59. Gilead Sciences Initiates Two Phase 3 Studies of Investigational Antiviral Remdesivir for the Treatment of COVID-19. Available from: https://www.gilead.com/news-and-press/press-room/ press-releases/2020/2/gilead-sciences-initiates-two-phase-3studies-of-investigational-antiviral-remdesivir-for-the-treatmentof-covid-19. [Last accessed on 2020 Feb 27].

60. Vincent MJ, Bergeron E, Benjannet S, Erickson BR, Rollin $\mathrm{PE}$, Ksiazek TG, et al. Chloroquine is a potent inhibitor of SARS coronavirus infection and spread. Virol J. 2005;2:69. PMid: 16115318

61. Zhou $\mathrm{Y}$, Vedantham $\mathrm{P}$, Lu K, Agudelo J, Carrion $\mathrm{R}$, Nunneley JW, et al. Protease inhibitors targeting coronavirus and filovirus entry. Antiviral Res. 2015;116:7684. $\quad$ https://doi.org/10.1016/j.antiviral.2015.01.011 PMid:25666761

62. Yamawaki H, Futagami S, Kaneko K, Agawa S, Higuchi K, Murakami $\mathrm{M}$, et al. Camostat mesilate, pancrelipase, and rabeprazole combination therapy improves epigastric pain in early chronic pancreatitis and functional dyspepsia with pancreatic enzyme abnormalities. Digestion. 2019;99(4):283-92. https://doi.org/10.1159/000492813 PMid:30391941

63. Ramsey ML, Nuttall J, Hart PA. TACTIC Investigative Team a phase $1 / 2$ trial to evaluate the pharmacokinetics, safety, and efficacy of $\mathrm{NI}-03$ in patients with chronic pancreatitis: Study protocol for a randomized controlled trial on the assessment of camostat treatment in chronic pancreatitis (TACTIC). Trials. 2019;20(1):501. https://doi.org/10.1186/s13063-019-3606-y PMid:31412955

64. Hoffmann M, Kleine-Weber $\mathrm{H}$, Krüger $\mathrm{N}$, Müller $\mathrm{M}$, Drosten $\mathrm{C}$, Pöhlmann S. The novel coronavirus 2019 (2019-nCoV) uses the SARS-coronavirus receptor ACE2 and the cellular protease TMPRSS2 for entry into target cells. bioRxiv. 2020;13(5):273. https://doi.org/10.1101/2020.01.31.929042

65. Kraft CS, Hewlett AL, Koepsell S, Winkler AM, Kratochvil CJ, Larson L, et al. The use of TKM-100802 and convalescent plasma in 2 patients with ebola virus disease in the United States. Clin Infect Dis. 2015;61(4):496-502. PMid:25904375

66. Walker LM, Burton DR. Passive immunotherapy of viral infections: "Super-antibodies" enter the fray. Nat Rev Immunol. 2018;18(5):297-308. https://doi.org/10.1038/nri.2017.148 PMid:29379211

67. Wong SK, Li W, Moore MJ, Choe H, Farzan M. A 193-amino acid fragment of the SARS coronavirus $S$ protein efficiently binds angiotensin-converting enzyme 2. J Biol Chem. 2004;279(5):3197-201. https://doi.org/10.1074/jbc.c300520200 PMid: 14670965 
68. Li W, Moore MJ, Vasilieva $\mathrm{N}$, Sui J, Wong SK Berne MA, et al. Angiotensin-converting enzyme 2 is a functional receptor for the SARS coronavirus. Nature. 2003;426(6965):450-4. https://doi.org/10.1038/nature02145 PMid:14647384

69. Elshabrawy HA, Coughlin MM, Baker SC, Prabhakar BS. Human monoclonal antibodies against highly conserved HR1 and HR2 domains of the SARS-CoV spike protein are more broadly neutralizing. PLoS One. 2012;7(11):e50366. https://doi.org/10.1371/journal.pone.0050366 PMid:23185609

70. Arbabi-Ghahroudi M. Camelid single-domain antibodies: Historical perspective and future outlook. Front Immunol. 2017;8:1589. $\quad$ https://doi.org/10.3389/fimmu.2017.01589 PMid:29209322

71. MooreMJ,DorfmanT,LiW,WongSK,LiY,KuhnJH, etal.Retroviruses pseudotyped with the severe acute respiratory syndrome coronavirus spike protein efficiently infect cells expressing angiotensin-converting enzyme 2. J Virol. 2004;78(19):1062835. https://doi.org/10.1128/jvi.78.19.10628-10635.2004 PMid:15367630

72. Imai Y, Kuba K, Rao S, Huan Y, Guo F, Guan B, et al. Angiotensinconvertingenzyme2protectsfromsevereacutelungfailure. Nature. 2005;436(7047):112-6. https://doi.org/10.1038/nature03712 PMid:16001071

73. Reilly J, Calfee C, Christie J. Acute respiratory distress syndrome phenotypes. Semin Respir Crit Care Med. 2019;40(1):19-30. https://doi.org/10.1055/s-0039-1684049 PMid:31060085

74. Khan A, Benthin C, Zeno B, Albertson TE, Boyd J, Christie JD, et al. A pilot clinical trial of recombinant human angiotensinconverting enzyme 2 in acute respiratory distress syndrome. Crit Care. 2017;21:234. https://doi.org/10.1186/s13054-017-1823-X

75. Maxmen A. More than 80 clinical trials launch to test coronavirus treatments. Nature. 2020;578(7795):347-8. https://doi.org/10.1038/d41586-020-00444-3 PMid:32071447

76. Wrapp D, Wang N, Corbett KS, Goldsmith JA, Hsieh CL, Abiona O, et al. Cryo-EM structure of the 2019-nCoV spike in the prefusion conformation. Science. 2020;367(6483):1260 3 PMid:32075877

77. Wolff JA, Malone RW, Williams P, Chong W, Acsadi G, Jani A, et al. Direct gene transfer into mouse muscle in vivo. Science. 1990;247(4949 Pt 1):1465-8. https://doi.org/10.1126/science.1690918 PMid:1690918

78. Sahin U, Karikó K, Türeci Ö. mRNA-based therapeutics developing a new class of drugs. Nat Rev Drug Discov. 2014;13(10):759-80. https://doi.org/10.1038/nrd4278 PMid:25233993

79. Sahin U, Derhovanessian E, Miller M, Kloke BP, Simon P, Löwer M, et al. Personalized RNA mutanome vaccines mobilize poly-specific therapeuticimmunityagainst cancer. Nature. 2017;547(7662):2226. https://doi.org/10.3410/f.727775310.793534716 PMid:28678784

80. Sebastian M, Schröder A, Scheel B, Hong HS, Muth A, von Boehmer L, et al. A phase I/lla study of the mRNA-based cancer immunotherapy CV9201 in patients with stage IIIB/ IV non-small cell lung cancer. Cancer Immunol Immunother. 2019;68(5):799-812. https://doi.org/10.1007/s00262-019-02315-x PMid:30770959

81. Diken M, Kranz LM, Kreiter S, Sahin U. mRNA: A versatile molecule for cancer vaccines. Curr Issues Mol Biol. 2017;22:113-28. https://doi.org/10.21775/cimb.022.113 PMid:27801664

82. Safety and Immunogenicity Study of 2019-nCov Vaccine (mRNA1273) to Treat Novel Coronavirus Full Text View. Available from: https://www.clinicaltrials.gov/ct2/show/NCT04283461. [Last accessed on 2020 Feb 27]. 